\title{
Sunflower meal and spring pea ruminal degradation protection using malic acid or orthophosphoric acid-heat treatments
}

\author{
F. Díaz-Royón ,J. M. Arroyo , M. D. Sánchez-Yélamo and J. González
}

\begin{abstract}
The effects of solutions of malic or orthophosphoric acids $(0.752 \mathrm{Eqg} / \mathrm{kg}$ of feed $)$ and heat to protect proteins of sunflower meal (SFM) and spring pea (SP) against ruminal degradation were studied using particle transit, ${ }^{15} \mathrm{~N}$ infusion, in situ and electrophoretic techniques. Three wethers fitted with rumen and duodenum cannulae were successively fed three isoproteic diets including SFM and SP, untreated or treated with malic or orthophosphoric acids. Incubations of tested meals were only performed while feeding the respective diet. Estimates of the ruminally undegraded fraction (RU) and its intestinal digestibility of dry matter, organic matter (only for RU), crude protein and starch (only in SP) were obtained considering ruminal microbial contamination and particle comminution and outflow rates. When corrected for microbial contamination, estimates of RU and intestinal digestibility decreased in all tested fractions for both feeds. All RU estimates increased with the protective treatments, whereas intestinal digestibility-dry matter also increased in SFM. Low intestinal digestibility-crude protein values suggested the presence of antitrypsin factors in SP. Protective treatments of both feeds led to consistent increases in the intestinal digested fraction of dry matter and crude protein, being only numerically different for SP-starch (60.5\% as average). However, treatments also reduced the organic matter fermentation, which may decrease ruminal microbial protein synthesis. Electrophoretic studies showed albumin disappearance in both SFM and SP, whereas changes in other RU proteins were more pronounced in SP than SFM.
\end{abstract}

Additional keywords: heat, malic and orthophosphoric acids, protein protection.

\section{Introduction}

Applying protective treatments against ruminal fermentation in high quality proteins is attractive to avoid their microbial degradation, which is usually associated with high ruminal ammonia losses and also with reduced efficiency of microbial protein synthesis (NRC 2001). The inefficiency associated with excessive ruminal protein degradation is important in productive ruminants, whose large amino acid requirements should be supplied mainly by protein concentrates. In particular, this inefficiency is large for concentrates composed of highly degradable proteins such as sunflower or spring pea meals (SFM and SP meals, respectively). In addition, amino acids from these protein concentrates are transformed into compounds such as nucleic bases or amino sugars that are not used for protein synthesis in animal tissues. In SFM, Arroyo et al. (2011, 2013) reported a large protection of crude protein (CP) by treating it with malic or ortophosphoric acid solutions and heat. These treatments increased bypass CP by 4.25 times, but the undigested fraction was increased as well, especially when using orthophosphoric acid. This protective effect was suspected to be the result of the high temperature applied $\left(150^{\circ} \mathrm{C}\right.$ during $\left.6 \mathrm{~h}\right)$, combined with the high moisture from the acid solution $(400 \mathrm{~mL} / \mathrm{kg})$. The objective of this study was to determine the effects of these treatments applied at lower temperature and moisture on rumen degradation and intestinal digestion of SFM and SP.

\section{Materials and methods \\ Meal treatments}

Samples of SFM and SP were treated with $4 \mathrm{~N}$ solutions $(200 \mathrm{~mL} / \mathrm{kg})$ of malic acid $(268.2 \mathrm{~g} / \mathrm{L})$ or orthophosphoric acid $(130.6 \mathrm{~g} / \mathrm{L})$. Acid doses were equivalent to those ( $2 \mathrm{~N}$ solutions sprayed at $400 \mathrm{~mL} / \mathrm{kg}$ ) used by Arroyo et al. (2013). Two fractions of $12.5 \mathrm{~kg}$ of each meal were successively sprayed with each acid solution in a concrete mixer using a sprayer. Both fractions were then mixed and allowed to rest for $1 \mathrm{~h}$ at room temperature. The blend was then dried in a forced air oven at $120^{\circ} \mathrm{C}$ for $1 \mathrm{~h}$. Then the oven was turned off and the treated material was left in the oven overnight. During the drying process, the material was stirred every $30 \mathrm{~min}$ during the first $2 \mathrm{~h}$ and then every $60 \mathrm{~min}$ for the subsequent $5 \mathrm{~h}$. 


\section{Diet and animals}

Diets were isoproteic and included $45 \%$ oat (Avena sativa) hay and $55 \%$ concentrate (fresh weight). The concentrate contained corn grain (30\%), barley grain (30\%), SFM (15\%), SP (22\%), and minerals and vitamin $(3 \%)$. The control diet (UT) included untreated SFM and SP, which were replaced by equivalent amounts of meals treated with malic or orthophosphoric acids in diets including treated meals (MT and PT, respectively). The CP supplied from SFM and SP represented $\sim 55 \%$ of total CP in all concentrates. Chemical composition of oat hay, SFM and SP meals and concentrates is shown in Table 1. Ranges of $C P$, neutral (NDF) and acid (ADF) detergent fibres of diets were $(\mathrm{g} / \mathrm{kg}$ of DM): $177-181,323-326$ and $150-154$, respectively. The DM intake was fixed at $45 \mathrm{~g} / \mathrm{kg}$ bodyweight $^{0.75}$ and diets were distributed in six equal meals (every $4 \mathrm{~h}$ ), starting at 0900 hours. The diets UT, PT and MT were offered successively in three experimental periods to three wethers (bodyweight $=$ $57.4 \pm 5.29 \mathrm{~kg}$ ) fitted with rumen cannulae (inside diameter $60 \mathrm{~mm}$ ) and T-type cannulae (inside diameter $12 \mathrm{~mm}$ ) in the proximal duodenum. Wethers were pen-housed individually and handled according to animal care principles published in the Spanish Royal Decree 1201/2005 (BOE 2005).

\section{Experimental procedures}

\section{Ruminal digestion}

The experimental period of 21 days included successively: 10 days of diet adaptation, SFM and SP particle transit study (Days 11-14) and ruminal nylon-bag incubations (Days 15-21). The rumen was emptied at 0900 hours at the end of in situ incubations in each period to isolate solid adherent bacteria (SAB) as described by Rodríguez et al. (2000). Rumen bacteria were labelled from Days 11 to 21 by continuous infusion $\left(250 \mathrm{~mL} /\right.$ day) of a $\left({ }^{15} \mathrm{NH}_{4}\right)_{2} \mathrm{SO}_{4}$ solution (98 atoms $\%$ enriched) that provided $25 \mathrm{mg}{ }^{15} \mathrm{~N} /$ day.wether.

The study of particle transit in the rumen-reticulum was performed by pulse dosing each animal before the first morning meal (i.e. at 0900 hours). Samples of $50 \mathrm{~g}$ of untreated SFM and SP were labelled with europium $(\mathrm{Eu})$ and ytterbium $(\mathrm{Yb})$, respectively, and were consumed completely in $20 \mathrm{~min}$. These meals had previously been washed in an automatic washer to eliminate soluble components, and marked by immersion in solutions of $\mathrm{Eu}_{2} \mathrm{Cl}_{3}$ or $\mathrm{YbCl}_{3}(10 \mathrm{mg}$ of $\mathrm{Eu}$ or $\mathrm{Yb} / \mathrm{g}$ of feed) as described by González et al. (1998). A total of 22 samples were obtained through the duodenal cannulae, the first sample before supplying the marker and the remaining samples between 1.5 and $96 \mathrm{~h}$ post-marker dosing. Samples were oven-dried at $105^{\circ} \mathrm{C}$ for $48 \mathrm{~h}$, milled to pass a $1-\mathrm{mm}$ screen, and analysed for $\mathrm{Eu}$ and $\mathrm{Yb}$. The pattern of Eu or $\mathrm{Yb}$ concentrations in the duodenal digesta over time was described for each animal by fitting to the model of Dhanoa et al. (1985). Primary and secondary rate constants used in this model were assumed as the rates of outflow $\left(k_{p}\right)$ and of comminution and mixing $\left(k_{c}\right)$ of particles in the reticulo-rumen, respectively, in agreement with Ellis et al. (1979) and González et al. (2006).

Ruminal incubations were performed using nylon bags ( 11 by 7-cm internal dimensions) with $46-\mu \mathrm{m}$ pore size and filled with $\sim 3 \mathrm{~g}$ (air-dry basis) of sample (ground to pass a 2-mm screen). Two series of ruminal incubations with 14 bags containing SFM (7) or SP (7) meals were carried out in each diet at 2, 4, 8, 16, 24, 48 and $72 \mathrm{~h}$. The meals incubated in each experimental period were those corresponding to the associated diet. In each incubation, all bags were placed simultaneously in the rumen just before the wethers were offered their first morning meal. Once collected from the rumen, bags were washed with tap water and stored at $-20^{\circ} \mathrm{C}$. After thawing, bags were washed three times for $5 \mathrm{~min}$ in a turbine washing machine (Jata 580; JATA, Abadiano, Bizkaia, Spain). The same washing procedure was applied for two series of two bags for each meal to obtain the 0 -h value. Bags were stored at $-20^{\circ} \mathrm{C}$ once again, freeze-dried and immediately weighed to establish degradation kinetics of dry matter (DM) with the exponential model of Ørskov and McDonald (1979):

$$
d=a+b\left(1-\mathrm{e}^{-k d t}\right)
$$

In this model, the constants $a$ and $b$ represent, respectively, the soluble fraction, (which was assumed as the 0 -h value) and the nonsoluble but degradable component, which disappears at a constant fractional rate, $k_{d}$, per unit time. The undegradable fraction $(r)$ was estimated as $1-(a+b)$.

Values of ruminally undegraded (RU) DM, organic matter (OM), CP and starch (only in SP) non-corrected or corrected for microbial contamination were determined considering degradation kinetics and both $k_{p}$ and $k_{c}$ transit rates with the method proposed by Arroyo and González (2013). This method is

Table 1. Chemical composition ( $\mathrm{g} / \mathrm{kg}$ of dry matter) of untreated (UT), malic acid treated (MT) and orthophosphoric acid treated (PT) of sunflower and spring pea meals, oat hay and used diets

$\mathrm{OM}$, organic matter; NDF, neutral detergent fibre; ADF, acid detergent fibre; CP, crude protein; NDIN and ADIN: insoluble nitrogen in neutral and acid detergent solutions, respectively

\begin{tabular}{|c|c|c|c|c|c|c|c|c|c|c|}
\hline \multirow[b]{2}{*}{ Item } & \multicolumn{3}{|c|}{ Sunflower meal } & \multicolumn{3}{|c|}{ Spring pea } & \multirow[t]{2}{*}{ Hay } & \multicolumn{3}{|c|}{ Diets } \\
\hline & UT & MT & PT & UT & MT & $\mathrm{PT}$ & & UD & $\mathrm{MD}$ & PD \\
\hline OM & 932 & 923 & 889 & 963 & 969 & 933 & 840 & 885 & 880 & 881 \\
\hline Starch & - & - & - & 368 & 367 & 370 & - & - & - & - \\
\hline NDF & 309 & 311 & 261 & 201 & 245 & 224 & 459 & 323 & 326 & 324 \\
\hline $\mathrm{ADF}$ & 177 & 184 & 159 & 85.3 & 94.5 & 103 & 236 & 154 & 150 & 151 \\
\hline Lignin & 28.2 & 44.7 & 32.5 & 2.44 & 1.79 & 2.38 & 46.6 & 26.7 & 26.9 & 25.4 \\
\hline $\mathrm{CP}$ & 344 & 322 & 346 & 221 & 210 & 212 & 189 & 181 & 177 & 178 \\
\hline $\operatorname{NDIN}(g / k g ~ N)$ & 137 & 151 & 103 & 125 & 180 & 150 & 358 & - & - & - \\
\hline $\operatorname{ADIN}(g / k g ~ N)$ & 41.9 & 47.3 & 38.2 & 18.8 & 21.9 & 23.0 & 54.2 & - & - & - \\
\hline
\end{tabular}


based on generating composite samples (CS) representative of the chemical composition of the RU feed. For this purpose, the residues obtained at each incubation time were pooled in equal quantities for each animal. The resultant residues for $0,2,4,8$, $16,24,48$ and $72 \mathrm{~h}$ of incubation were considered representative of the composition of the rumen outflow of undegraded feed in the intervals $0-1,1-3,3-6,6-12,12-20,20-36,36-60$ and $60-84 \mathrm{~h}$, respectively. The proportions in which the different residues were mixed were calculated by the ratio of the flow in each interval and the total flow determined using the feed flow-function proposed by Arroyo and González (2013). The $\mathrm{CS}$ were analysed for $\mathrm{OM}, \mathrm{CP},{ }^{15} \mathrm{~N} /$ total $\mathrm{N}$ and starch (only in $\mathrm{SP}$ ). The respective RU values (as \%) were determined from the concentrations of the tested fraction in the composite samples $(\mathrm{Y})$ and in the whole feed $(\mathrm{X})$ and the RU-DM values, as follows:

$$
\mathrm{RU}-\mathrm{MO},-\mathrm{CP} \text { or }-\operatorname{starch}=\mathrm{Y} \times \mathrm{RU}-\mathrm{DM} / \mathrm{X}
$$

The microbial proportions of $\mathrm{N}$ and DM in CS were determined as indicated by Rodríguez and González (2006) using SAB samples as reference; $\mathrm{SAB}$ isolates were lyophilised and analysed for DM, OM, N, ${ }^{15} \mathrm{~N} / \mathrm{N}$ and total glucose. Microbial proportions of $\mathrm{OM}$ and glucose were determined as the microbial DM content of CS samples $\times$ the concentration of these fractions in $\mathrm{SAB}$ expressed on DM.

\section{Intestinal digestion}

Twenty days after the end of the ruminal studies, wethers were fed again the untreated diet to determine ID-DM, -CP and -starch of untreated and treated meals. Eight subsamples of $200 \mathrm{mg}$ of each CS were put into round-shaped (approximate diameter $2.5 \mathrm{~cm}$ ) mobile nylon bags. These bags were inserted randomly through the duodenal cannulae of the respective wether at a rate of one bag every $15 \mathrm{~min}$ for $2 \mathrm{~h}$ for a total of 8 bags/day.wether, and recovered from the faeces. Bags were then processed by the same methods as those for rumen incubations; bags were then dried at $80^{\circ} \mathrm{C}$ for $48 \mathrm{~h}$ and weighed. The ID-DM was calculated as DM disappearance from the bag during intestinal incubation. Undigested residues obtained in each wether were pooled and analysed for CP, ${ }^{15} \mathrm{~N} / \mathrm{N}$ and starch (only in SP). The ID for any fraction was determined as the proportions from the ID-DM value and concentration of this fraction in the CS (Y) and in the intestinal incubated residues $(Z)$ :

$$
\mathrm{ID}-\mathrm{CP} \text { or }-\operatorname{starch}=1-[\mathrm{Z} \times(1-\mathrm{ID}-\mathrm{DM}) / \mathrm{Y}]
$$

The ${ }^{15} \mathrm{~N} / \mathrm{N}$ ratio was used to correct for the residual contamination due to adherent rumen microorganisms as previously indicated.

\section{Protein electrophoresis}

Protein in untreated and treated meals and their $0 \mathrm{~h}$, composite and intestinally undigested samples were extracted and subjected to electrophoresis to determine the digestion site of the different protein fractions.

\section{Chemical and protein electrophoresis analyses}

Feed samples were analysed in triplicate using AOAC (2000) procedures for DM (procedure 934.01), ash (procedure 967.05) and CP $(6.25 \times$ Dumas N; procedure 968.06), NDF (Van Soest et al. 1991) and sequential $\mathrm{ADF}$ and acid detergent lignin (Robertson and Van Soest 1981). Analyses of NDF were performed with $\alpha$-amylase and without sodium sulfite. NDF and ADF were expressed including the residual ash. The insoluble $\mathrm{N}$ in neutral and acid detergent solutions was determined by $\mathrm{N}$ analysis of the NDF and ADF residues, respectively. Ruminal or intestinal incubated residues were also analysed for $\mathrm{N}$ with the Dumas method. Samples of duodenal contents collected for transit studies were analysed by atomic absorption ( $\mathrm{Yb}$ ) or emission ( $\mathrm{Eu}$ ) spectrometry, as described by González et al. (1998). N isotopic proportions were performed in an elementary analyser (Flash 1112, Thermo, Bremen, Germany) coupled in continuous flow to an isotope ratio mass spectrometer (Delta V, Thermo).

Homogenate samples of the different protein fractions of SFM and SP were extracted using different solutions: (1) TRIS-HCl pH $6.81 \mathrm{M}, 10 \%$ glycerol, $2.5 \% \mathrm{SDS}$ and $5 \%$ $\beta$-mercaptoethanol to obtain total protein (2) $0.4 \mathrm{M} \mathrm{NaCl}+3 \%$ $\beta$-mercaptoethanol to obtain globulins and (3) water to obtain albumins. Solutions were used at $750 \mu \mathrm{L}$ per $\mathrm{mg}$ of $\mathrm{N}$. The extracts were agitated in a vortex and left overnight with gentle stirring at $4^{\circ} \mathrm{C}$. After centrifugation $\left(12500 \mathrm{~g}\right.$ for $45 \mathrm{~min}$ at $\left.4^{\circ} \mathrm{C}\right)$ and pellet removal, the supernatant was mixed with a reducing buffer $(1: 1, \mathrm{v} / \mathrm{v})$ and boiled for $10 \mathrm{~min}$ in a water bath. Electrophoresis was carried out using polyacrylamide slab gels [sodium dodecyl sulfate-polyacrylamide gel electrophoresis $($ SDS-PAGE); $160 \times 155 \times 1 \mathrm{~mm}]$ following the Laemmli (1970) protocol modified by Sánchez-Yélamo (in Vázquez et al. 2000). For total proteins and globulins, $10 \mu \mathrm{L}$ per sample were applied, whereas for albumins, 20, 30 and $40 \mu \mathrm{L}$ per well were tested because fewer proteins were detected in the gels. In all cases the electrode buffer was cold Tris-glycine $(\mathrm{pH} 8.3)$ and bromophenol blue was used as front-dye marker. The molecular weights (MW) of the protein samples were determined using a standard protein marker (Invitrogen Mark 12) consisting of myosin (MW $200 \mathrm{KD}$ ), $\beta$-galactosidase (MW 116.3 KD), phosphorylase b (MW 97.4 KD), serum albumin (MW 66.3 KD), glutamic dehydrogenase (MW 55.4 KD), lactate dehydrogenase (MW 36.5 KD), carbonic anhydrase (MW 31.0 KD), trypsine inhibitor (MW 21.5 KD), lysozyme (MW 14.4 KD) and aprotinin (MW 6.0 KD). After electrophoresis ( 4.5 h), gels were stained overnight at room temperature with Coomassie Brilliant blue R-250 followed by de-staining twice in acetic acid: 2-propanol $10 \%(\mathrm{v} / \mathrm{v})$ for $4 \mathrm{~h}$. At least three repetitions were made to check for the reproducibility of the electrophoretic patterns. In each band pattern, bands were numbered in ascending order from cathode to anode starting with band ' 1 '. The identity of each band was estimated by its relative mobility on the gel, and the molecular masses were estimated using a calibration curve developed with the marker standard polypeptides. Several specific proteins were identified by comparison with data from the literature.

\section{Statistical methods}

Degradation and transit kinetics were fitted by non-linear regression. Effects of protective treatments $(t)$ on apparent parameters of DM degradation kinetics and RU-DM were 
studied by variance analysis considering these factors and the wethers $(w)$ in the model $\left(y_{i j}=\mu+t_{i}+w_{j}+\varepsilon_{i j}\right)$. These same effects and those of the correction of microbial contamination taking place in the rumen $(c)$ of RU, ID and the intestinal absorbable dietary fraction (IADF $=$ RU $\times$ ID) values were studied by variance analyses in a split-plot arrangement of treatments. In this design, the treatment was the whole-plot, tested against the wether $\times$ treatment interaction as the error term, and microbial correction and its interaction with treatment were the subplot treatments $\left(y_{i j k}=\mu+t_{i}+w_{j}+c_{k}+t_{i} \times c_{k}+t_{i} \times w_{j}+\varepsilon_{i j k}\right)$. These means were examined by orthogonal contrasts for treatment effects (untreated vs treated) and of acid used (malic vs orthophosphoric acids). This same design substituting microbial correction by the transit model considered ( $k_{p}$ alone compared with $k_{p}$ and $k_{c}$ ) was also used to examine the differences in $\mathrm{RU}$ estimates of the insoluble but potentially degradable fraction of DM. As the animals were adult, maintained in a controlled environment, the period effect was assumed to be negligible in all variance analysis. Effects were declared significant at $P<0.05$. All statistical analyses were performed using SAS software, version 8.0 (SAS 1999).

\section{Results}

\section{Feed digestion}

There were no differences among treatments or between the two meals (SFM, SP) in the $k_{p}$ or $k_{c}$ values: $k_{p}: 6.36 \% / \mathrm{h}$ versus $5.53 \% / \mathrm{h}$; s.e.m. $=0.295 ; P=0.227 ; k_{c}: 77.7 \% / \mathrm{h}$ versus $56.2 \% / \mathrm{h}$; s.e.m. $=7.05 ; P=0.153$. Therefore, mean values for each feed were used to calculate RU values in untreated and treated meals.

In treated SFM and SP, the soluble fraction of DM (a) decreased and the potentially degradable fraction (b) increased; however, the undegradable fraction $(r)$ was increased except when SFM was treated with orthophosphoric acid (Table 2). In addition, both treatments led to reductions of $k_{d}$ in SFM whereas reductions in $k_{d}$ for SP were only numerical. As a result of these changes, treatments increased the apparent RU-DM corresponding to both the $b$ fraction and total feed in both SFM and SP. There was no clear evidence of differences in the protective effect between both acids, especially for SP. The omission of $k_{c}$ from the model resulted in mean values ( \pm s.e.) of the RU-DM of the $b$ fraction for UT, MT and PT meals of: $16.2( \pm 2.14), 22.2( \pm 1.19)$ and $22.1( \pm 1.67) \%$ in SFM and $18.4( \pm 1.48), 26.5( \pm 1.86)$ and $24.3( \pm 1.80) \%$ in SP, respectively. These values were higher $(P<0.001)$ than those generated when $k_{p}$ and $k_{c}$ were included in the calculations which are indicated in Table 2. Therefore, omitting $k_{c}$ overestimated the apparent RU- $b$ of DM of UT, MT and PT meals, respectively, by $16.8,11.0$ and $12.4 \%$ in SFM, and by $20.1,15.7$ and $18.2 \%$ in $\mathrm{SP}$ (data not shown).

The microbial contamination with DM or $\mathrm{N}$ in CS samples of both feeds showed large variability, and treatment effects were undetected. The large variability observed for the disappearance of DM biomass during the intestinal incubation in SP also prevented detecting effects, which on the contrary were shown for SFM (Table 3). Not correcting ruminal microbial contamination led to consistent overestimations in RU, ID and IADF values of all tested variables in both tested feeds
Table 2. Effects of protective treatments on apparent rumen degradation kinetics and ruminal undegraded fraction (RU) of dry matter of sunflower and spring pea meals (values are expressed as \%)

\begin{tabular}{lcccccc}
\hline & \multicolumn{5}{c}{ Meals } & \multicolumn{3}{c}{ Probability of contrasts } \\
& UT $^{\mathrm{B}}$ & MT & PT & s.e.m. & C1 & C2 \\
\hline \multicolumn{7}{c}{ Sunflower meal } \\
$a^{\mathrm{C}}$ & 31.6 & 26.3 & 26.2 & - & - & - \\
$b$ & 50.2 & 52.0 & 55.6 & 4.65 & 0.003 & 0.006 \\
$r$ & 18.3 & 21.6 & 18.2 & 4.65 & 0.045 & 0.006 \\
$k_{d}(\% / h)$ & 14.0 & 8.64 & 9.94 & 1.13 & 0.027 & 0.464 \\
RU & 32.2 & 41.6 & 37.9 & 0.72 & 0.001 & 0.021 \\
RU-b & 13.9 & 20.0 & 19.7 & 1.03 & 0.009 & 0.844 \\
& & & Spring pea & & & \\
$a$ & 38.9 & 23.2 & 21.6 & - & - & - \\
$b$ & 55.8 & 68.2 & 68.8 & 1.27 & 0.001 & 0.764 \\
$r$ & 5.29 & 8.56 & 9.60 & 1.27 & 0.071 & 0.592 \\
$k_{d}(\% / h)$ & 11.7 & 8.95 & 10.5 & 0.92 & 0.153 & 0.311 \\
RU & 20.6 & 31.4 & 30.2 & 1.04 & 0.001 & 0.427 \\
RU-b $b$ & 15.3 & 22.9 & 20.6 & 1.38 & 0.019 & 0.300 \\
\hline
\end{tabular}

${ }^{\mathrm{A}} \mathrm{UT}$, MT and PT: meals untreated or treated with malic or ortophosphoric acids, respectively.

${ }^{\mathrm{B}} \mathrm{C} 1$ : UT versus treated meals; $\mathrm{C} 2$ : MT versus PT.

$c_{a, b}$, and $r$ represent soluble, non-soluble degradable and undegradable fractions, respectively. $k_{d}$ : fractional degradation rate of fraction $b$. RU: ruminally undegraded fraction. RU- $b$ : RU corresponding to the $b$ fraction, calculated using ruminal rates of particle comminution $\left(k_{c}\right)$ and outflow $\left(k_{p}\right)$ as: $\mathrm{RU}=r+\mathrm{RU}-b$ and $\mathrm{RU}-b=b k_{c} k_{p} /\left[\left(k_{d}+k_{p}\right)\left(k_{d}+k_{c}\right)\right]$.

Table 3. Microbial contamination of ruminal undegraded composite samples of sunflower meal (SFM) and spring pea (SP)

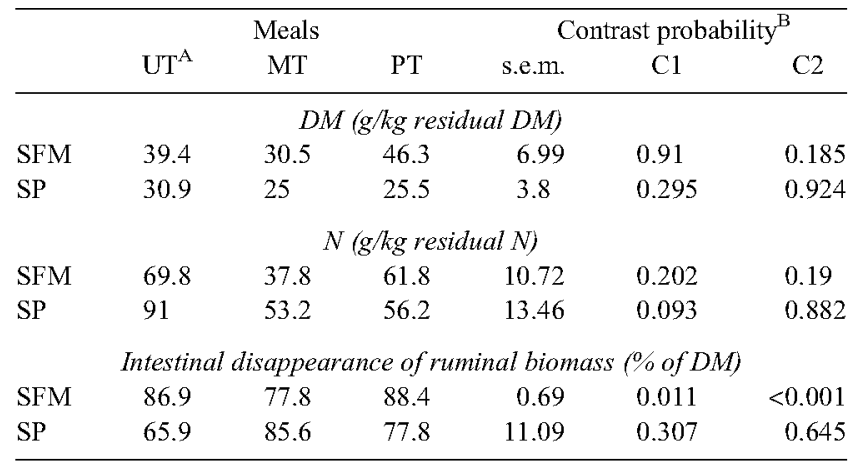

${ }^{\mathrm{A}} \mathrm{UT}$, MT and PT: meals untreated or treated with malic or ortophosphoric acids, respectively.

${ }^{\mathrm{B}} \mathrm{C}$ : UT versus treated meals; $\mathrm{C} 2$ : MT versus $\mathrm{PT}$.

(Tables 4, 5). As previously indicated for DM, protective treatments consistently increased RU in the remainder tested fractions in both feeds. Also, positive effects were shown in the ID-DM in SFM, but not for ID-CP in this meal or for the different SP-tested fractions. As a result, treatments also increased the IADF-DM and IADF-CP in both tested meals (Tables 4, 5). Despite the fact that treatments increased the IADF-starch by $60.5 \%$ on average, the results were not statistically significant, probably due to the high variability observed (Table 5). Regression analysis showed strong correlations between microbial-corrected values of both 
Table 4. Effects of protective treatments and of correcting the microbial contamination taking place in the rumen on in situ estimates of ruminally undegraded fraction (RU), intestinal digestibility (ID) and intestinal absorbable dietary fraction (IADF: RU $\times$ ID) of sunflower meal

\begin{tabular}{|c|c|c|c|c|c|c|c|c|c|c|c|}
\hline & \multicolumn{6}{|c|}{ Meals $^{\mathrm{A}}$} & \multicolumn{5}{|c|}{ Effects and contrasts ${ }^{\mathrm{B}}$} \\
\hline & \multicolumn{2}{|c|}{ UT } & \multicolumn{2}{|c|}{ MT } & \multicolumn{2}{|c|}{ PT } & \multicolumn{3}{|c|}{ Treatments } & \multicolumn{2}{|c|}{ Correction } \\
\hline \multicolumn{12}{|c|}{$R U$} \\
\hline Dry matter & 32.2 & 30.9 & 41.6 & 40.3 & 37.9 & 36.1 & 0.61 & $<0.001$ & 0.010 & 0.17 & $<0.001$ \\
\hline Organic matter & 32.8 & 31.8 & 43.4 & 42.3 & 40.5 & 39.0 & 0.61 & $<0.001$ & 0.022 & 0.14 & $<0.001$ \\
\hline Crude protein & 21.4 & 19.9 & 42.2 & 40.6 & 33.0 & 30.9 & 0.61 & $<0.001$ & $<0.001$ & 0.19 & $<0.001$ \\
\hline \multicolumn{12}{|c|}{$I D$} \\
\hline \multicolumn{12}{|c|}{$I A D F$} \\
\hline Dry matter & 9.71 & 8.58 & 16.0 & 14.5 & 15.3 & 13.6 & 1.15 & 0.012 & 0.628 & 0.24 & 0.005 \\
\hline Crude protein & 17.5 & 15.2 & 35.5 & 32.5 & 28.6 & 24.3 & 1.24 & $<0.001$ & 0.013 & 0.51 & 0.004 \\
\hline
\end{tabular}

${ }^{\mathrm{A}} \mathrm{UT}, \mathrm{MT}$ and PT: meals untreated or treated with malic or ortophosphoric acids, respectively.

${ }^{\mathrm{B}} \mathrm{C} 1$ : UT versus treated meals; $\mathrm{C} 2$ : MT versus PT.

$\mathrm{NC}$ and $\mathrm{C}$ : no corrected and corrected by the ruminal microbial contamination.

Table 5. Effects of protective treatments and of correcting the microbial contamination taking place in the rumen on in situ estimates of ruminally undegraded fraction (RU), intestinal digestibility (ID) and intestinal absorbable dietary fraction (IADF: RU $\times$ ID) of spring pea

\begin{tabular}{|c|c|c|c|c|c|c|c|c|c|c|c|}
\hline & \multicolumn{6}{|c|}{ Meals $^{A}$} & \multicolumn{5}{|c|}{ Effects and contrasts ${ }^{\mathrm{B}}$} \\
\hline & \multicolumn{2}{|c|}{ UT } & \multicolumn{2}{|c|}{ MT } & \multicolumn{2}{|c|}{ PT } & \multicolumn{3}{|c|}{ Treatments } & \multicolumn{2}{|c|}{ Correction } \\
\hline \multicolumn{12}{|c|}{$R U$} \\
\hline Dry matter & 20.6 & 20.0 & 31.4 & 30.7 & 30.2 & 29.4 & 1.06 & 0.001 & 0.449 & 0.09 & 0.002 \\
\hline Organic matter & 21.0 & 20.5 & 31.9 & 31.3 & 31.4 & 30.8 & 1.04 & 0.001 & 0.749 & 0.07 & 0.001 \\
\hline Crude protein & 13.0 & 11.9 & 28.2 & 26.7 & 26.1 & 24.7 & 1.14 & $<0.001$ & 0.270 & 0.16 & 0.001 \\
\hline Starch & 15.4 & 15.4 & 29.2 & 29.1 & $\begin{array}{r}25.9 \\
I I\end{array}$ & 25.8 & 2.01 & 0.008 & 0.300 & 0.007 & 0.003 \\
\hline Dry matter & 32.1 & 30.8 & 32.9 & 31.6 & 35.9 & 34.7 & 1.90 & 0.373 & 0.313 & 0.22 & 0.006 \\
\hline Crude protein & 35.2 & 24.8 & 37.5 & 28.1 & 38.6 & 29.8 & 2.00 & 0.222 & 0.659 & 1.68 & 0.007 \\
\hline Starch & 64.7 & 64.2 & 54.5 & 53.6 & $\begin{array}{r}62.7 \\
I A I\end{array}$ & 62.1 & 6.63 & 0.484 & 0.427 & 0.12 & 0.007 \\
\hline Dry matter & 6.64 & 6.17 & 10.3 & 9.67 & 10.8 & 10.2 & 0.66 & 0.009 & 0.597 & 0.09 & 0.003 \\
\hline Crude protein & 4.57 & 2.99 & 10.6 & 7.47 & 10.0 & 7.43 & 0.70 & 0.004 & 0.782 & 0.37 & 0.003 \\
\hline Starch & 10.1 & 9.97 & 16.0 & 15.7 & 16.5 & 16.3 & 2.93 & 0.164 & 0.890 & 0.03 & 0.005 \\
\hline
\end{tabular}

${ }^{\mathrm{A}} \mathrm{UT}$, MT and PT: meals untreated or treated with malic or ortophosphoric acids, respectively.

${ }^{\mathrm{B}} \mathrm{C} 1$ : UT versus treated meals; $\mathrm{C} 2$ : MT versus PT.

$\mathrm{C}_{\mathrm{NC}}$ and $\mathrm{C}$ : no corrected and corrected by the ruminal microbial contamination.

RU-DM and ID-DM in SFM (ID-DM $=-0.55+0.955$ RU-DM; $\left.n=9 ; R^{2}=0.654 ; P=0.008\right)$. Similar relationships were also shown between IADF and RU of all tested parameters in both feeds (Fig. 1). In SFM, malic acid showed higher protective efficiency than orthophosphoric acid for RU values as well as for IADF-CP (Table 4); this was not observed for SP (Table 5).

\section{Protein electrophoresis}

Gel electrophoresis of total proteins, globulins and albumin are shown in Fig. 2 (SFM) and Fig. 3 (SP). In both feeds, images of treated meals were less sharp than those observed in untreated meals, especially in those samples not subjected to washing processes before protein extraction and electrophoresis.
Profiles of SFM showed clear bands for polypeptides in an approximate range of MW of 56 to $6 \mathrm{KD}$, whereas those of SP fell within a range of 97.4-6 KD.

Albumin was not detected in 0 -h samples of SFM nor in those of protected SP meals. In addition, they were not detected in both feeds, untreated or treated CS samples. Similarly, the gel of total proteins of CS samples showed lack of some polypeptides other than albumin in untreated or treated SFM (3,13 and 14) and $\mathrm{SP}(1,2,4,6,12,14$ and 21$)$. Furthermore, some polypeptides $(10,13$ and 20$)$ were not detected in the gel of globulins in untreated or treated CS samples of SP. Finally, polypeptides were not observed in intestinal-incubated residues of SFM or SP, with the exception of some diffuse shading in areas corresponding to polypeptides of low MW $(<10 \mathrm{KD})$ identified as 15,16 and 18 . 


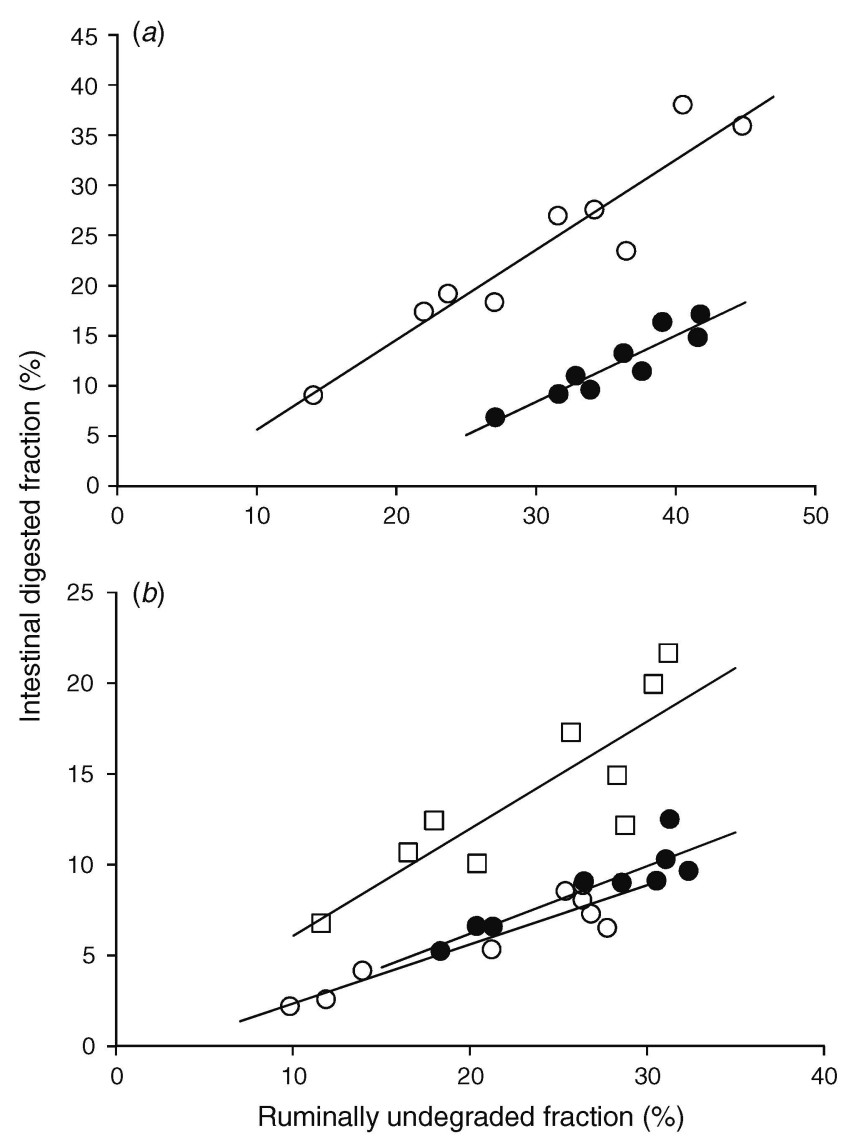

Fig. 1. Relationships between intestinal digested (IADF) and ruminally undegraded $(\mathrm{RU})$ fractions of dry matter $(\bullet)$, crude protein $(\bigcirc)$ and starch $(\square)(a)$ in sunflower meal (SFM) and $(b)$ spring pea (SP). Equations: SFM: DM: IADF $=-11.47+0.663 \mathrm{RU} ; R^{2}=0.861 ; P<0.001$. CP: IADF $=-3.34+0.898 \mathrm{RU} ; R^{2}=0.861 ; P<0.001$. SP: DM: IADF $=-1.23+0.371$ $\mathrm{RU} ; R^{2}=0.813 ; P<0.001 ; \mathrm{CP}: \mathrm{IADF}=-0.90+0.323 \mathrm{RU} ; R^{2}=0.867$; $P<0.001$; Starch: IADF $=0.17+0.590$ RU; $R^{2}=0.861 ; P<0.001$.

\section{Discussion}

The chemical composition of the SFM sample may be considered normal except for its low fibre fractions in relation to its CP content. By contrast, the SP sample showed a high fibre content.

\section{Accuracy of in situ estimates}

The omission of the $k_{c}$ rate from the calculations of in situ degradation may have an effect on the in situ digestive estimates through its influence on the digestion site (ARC 1984). In relation to the total mean residence time in the rumen-reticulum, the time associated with the $k_{c}$ rate was considerable $(7.6 \%$ and $9.0 \%$ as mean in SFM and SP, respectively), supporting the consideration of this rate to improve accuracy of in situ estimates, as previously indicated (Arroyo and González 2013). The overestimation of the feed bypass caused by the lack of correction of the microbial contamination of rumen-incubated residues may also lead to overestimations of ID due to the large intestinal digestion of these adherent microorganisms. Both overestimations are directly
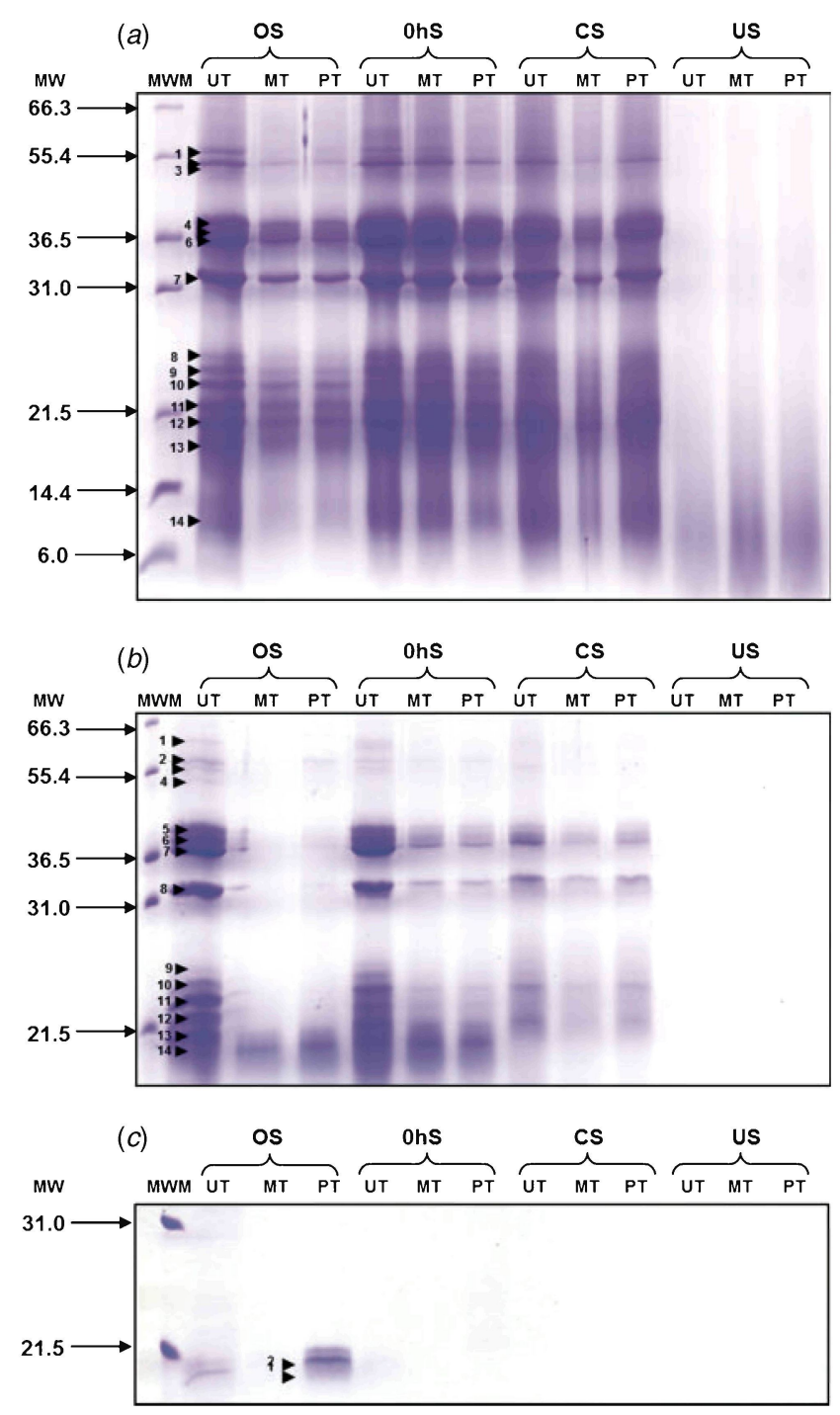

Fig. 2. SDS-gel electrophoresis of $(a)$ total proteins, $(b)$ globulins and (c) albumin of original (OS), $0 \mathrm{~h}(0 \mathrm{hS})$, ruminally undegraded (CS) and intestinal undigested (US) samples of untreated (UT), malic acid treated (MT) and orthophosphoric acid-treated (PT) sunflower meal.

related to the extent of microbial contamination (Rodríguez and González 2006), whereas the difference in intestinal disappearance between $\mathrm{SAB}$ and bypass compounds is also a major factor affecting ID overestimations (Arroyo and González 2013), which is in agreement with the large overestimations shown in ID-CP of SP. Current values for SFM showed higher contaminations ( 4.0 and 3.1 times as average of the three meals for the DM and CP, respectively), than those observed in another SFM sample of a previous similar experiment carried out with the same doses of both acids (Arroyo et al. 2013). As a consequence, RU and ID overestimations in the current sample were also largely higher.

\section{Protective treatments}

The reduction in degradability with the protective treatments in both tested meals was due to a decrease in the soluble fraction 

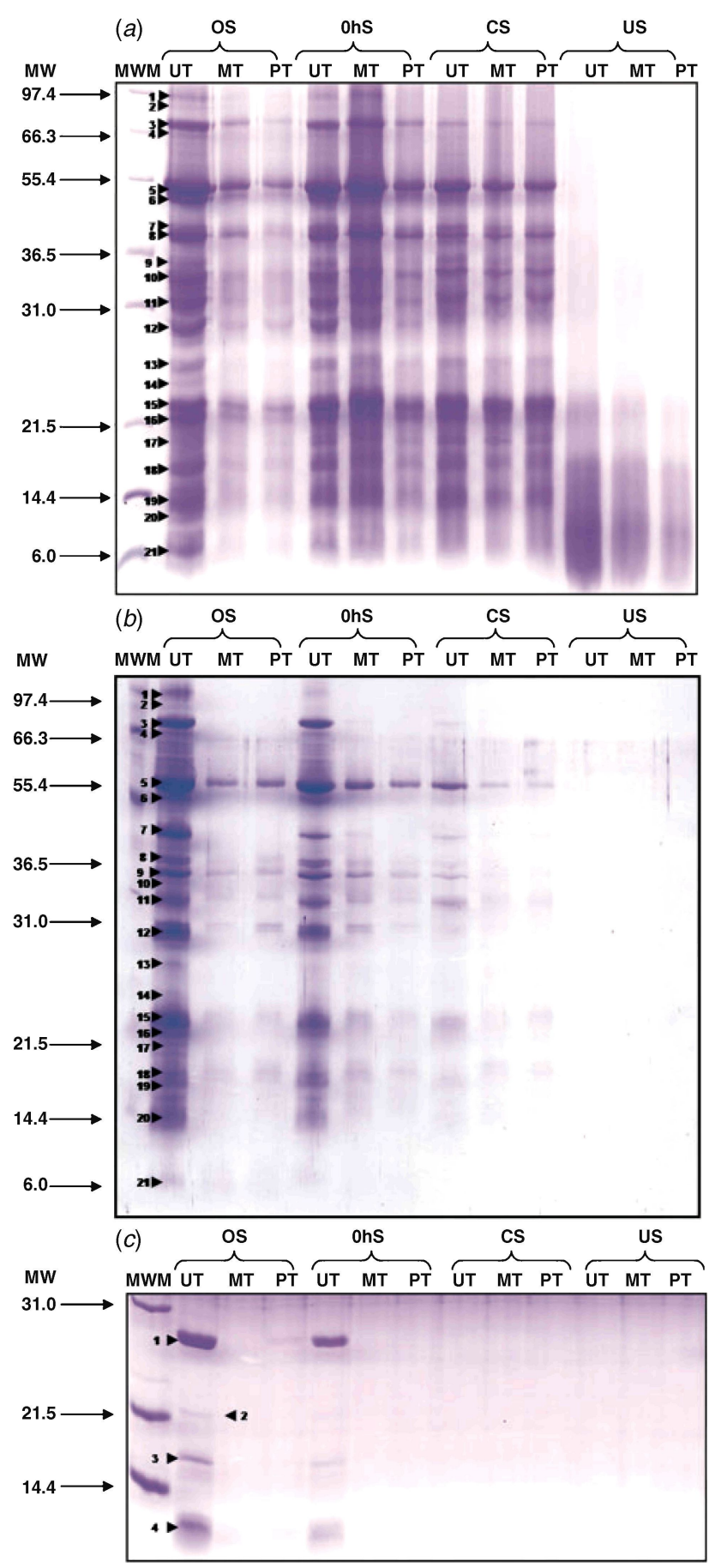

Fig. 3. SDS-gel electrophoresis of $(a)$ total proteins, $(b)$ globulins and (c) albumin of original (OS), $0 \mathrm{~h}(0 \mathrm{hS})$, ruminally undegraded (CS) and intestinal undigested (US) samples of untreated (UT), malic acid treated (MT) and orthophosphoric acid-treated (PT) spring pea.

and increased $b$ fractions, which in addition were degraded more slowly. In consequence, treatments increased the $b$-RU fraction and, therefore, shifted the digestion site to the intestine. However, these effects were lower in SFM compared with previous results by Arroyo et al. (2013). The decrease in ruminal DM digestibility in SFM was mainly the result of decreased degradation of CP.
Thus, microbial-corrected values showed that the reduction in degraded CP represented 86.8\% (with malic acid) and 70.1\% (with orthophosphoric acid) of the reduction in ruminally digested DM. This was not the case in SP, which displayed respective values for this contribution of $35.8 \%$ and $31.6 \%$, in agreement with its moderate CP content. Equivalent values for starch were $47.4 \%$ and $38.8 \%$, respectively. These results show that degradation of components other than proteins is also affected by these treatments in both feeds.

Observed increases of RU-CP in treated SFM were lower than those reported in Arroyo et al. (2013). In addition, in the experiment aforementioned, associated increases of ID-CP were observed, whereas increases seen in the present experiment were not statistically significant. As a result the increments in microbial-corrected values of IADF-CP $(113.8 \%$ and $59.9 \%$ for malic and orthophosphoric acids-treated meals, respectively), were also lower than in Arroyo et al. (2013). This lower protection efficiency may be associated with the lower CP degradability of the present untreated SFM sample, but mainly with the lower levels of moisture and heat applied in the present experiment. The similar behaviour observed with treatments in SP also support this limited protection efficiency. This fact was augmented in SP by its extremely low ID-CP, which reduces the benefits associated with changing the digestion site to the intestine. Thus, the contents of feed-undigested CP in the total tract were $8.88 \%$ in UT, $19.2 \%$ in MT and $17.2 \%$ in PT. The low ID-CP observed in SP cannot be associated with a high concentration of indigestible compounds in the RU fraction. Thus, low values were observed both in the untreated meal and in the treated meals, which showed RU fractions 2.15 times higher on average than the untreated meal. On the contrary, it suggests the presence of a non-heat labile antitrypsin factor in SP. Thus, the results of ruminal degradability of DM, CP and starch in the untreated SP sample were close to those proposed by the INRA (2007): $80 \%, 86 \%$ and 79\%, respectively, whereas INRA (2007) suggests intestinal digestibility of CP of $91 \%$; 2.5 times higher than the average values for untreated and treated SP meals reported in this study.

Changes with protective treatments in RU and ID demonstrate that the close relationships shown between IADF and RU for both feeds are mainly from the decrease in rumen degradation, although in SFM the increase of ID-DM also contributed to the increased IADF value. Differences in the regression coefficients among chemical fractions also show differential effects of these treatments, which were higher for CP in SFM and for starch in SP.

The increased supply of intestinally digested CP from treated meals should also be associated with a decrease in the ruminal microbial protein synthesis owing to their reduced $\mathrm{OM}$ degradation. Based on corrected results of IADF-CP and OM degradability (calculated as 100-RU) and the parameters of ruminal synthesis and intestinal availability of microbial protein in the PDI system (INRA 2007), the total supply of intestinal digestible protein from SFM samples was 111.7, 154.3 and $134.9 \mathrm{~g} / \mathrm{kg} \mathrm{DM}$ in UT, MT and PT meals, respectively. Similar values in SP were 78.0, 77.6 and $76.1 \mathrm{~g} / \mathrm{kg}$ DM. When $\mathrm{CP}$ concentrations of the meals were considered, protective treatments using malic or orthophosphoric acids respectively increased the protein value by $47.5 \%$ and $20.1 \%$ in SFM and 
Table 6. Range of estimated molecular mass of polypeptidic bands detected by SDS-PAGE in sunflower meal and spring pea studied samples

\begin{tabular}{|c|c|c|c|c|c|c|c|}
\hline & & Sunflower meal & & & & pring pea & \\
\hline $\begin{array}{l}\text { Band } \\
\text { no. }\end{array}$ & $\begin{array}{l}\text { Range of molecular } \\
\text { mass }(\mathrm{KD})\end{array}$ & Protein nomenclature & References & $\begin{array}{c}\text { Band } \\
\text { no. }\end{array}$ & $\begin{array}{c}\text { Range of } \\
\text { molecular mass }(\mathrm{KD})\end{array}$ & Protein nomenclature & References \\
\hline 1 & 56 & Unknown & & $\left.\begin{array}{l}1 \\
2\end{array}\right\}$ & $96-91$ & Unknown & \\
\hline 2 & 53 & Unknown & & $\left.\begin{array}{l}3 \\
4\end{array}\right\}$ & $70-68$ & Convicilin subunits & {$[1,2,3,4,5]$} \\
\hline 3 & 46 & Unknown & & $\left.\begin{array}{l}5 \\
6\end{array}\right\}$ & $55-53$ & Vicilins (50 KD) & {$[2,3,4]$} \\
\hline $\left.\begin{array}{l}4 \\
5 \\
6\end{array}\right\}$ & $40-30$ & Helianthinin (larger polipeptides) & {$[2,3,6]$} & $\left.\begin{array}{l}7 \\
8\end{array}\right\}$ & $40-45$ & $\alpha$ legumin $(40 \mathrm{KD})$ & {$[2,3,4]$} \\
\hline 7 & 33 & Unknown & & $\left.\begin{array}{r}9 \\
10 \\
11\end{array}\right\}$ & $36.5-31$ & Vicilins (30 KD) & {$[2,3,4]$} \\
\hline $\left.\begin{array}{l}8 \\
9 \\
10\end{array}\right\}$ & $27-23$ & Helianthininm (smaller polipeptides) & {$[2,3,6]$} & $\left.\begin{array}{l}12 \\
13 \\
14 \\
15 \\
16 \\
17\end{array}\right\}$ & $30-20$ & $\beta$-legumin and vicilins & {$[2,3,4]$} \\
\hline $\left.\begin{array}{l}11 \\
12 \\
13 \\
14\end{array}\right\}$ & $21.5-15$ & Albumins & {$[8,9]$} & $\left.\begin{array}{l}18 \\
19 \\
20 \\
21\end{array}\right\}$ & $20-6$ & $\begin{array}{c}\text { Vicilins (of lower mol. } \\
\text { mass) and albumins }\end{array}$ & {$[2,3,4,5]$} \\
\hline
\end{tabular}

[1] Croy et al. (1980); [2] Derbyshire et al. (1976); [3] Casey (1999); [4] Casey and Domoney (1999); [5] O'Kane et al. (2004); [6] Allen et al. (1985); [7] Kortt and Cadwell (1990); [8] Kortt et al. (1991); [9] Shewry and Pandya (1999).

by $4.95 \%$ and $1.79 \%$ in SP. These increases may be somewhat higher than the above calculated values due to a higher efficiency of microbial synthesis associated with the reduction of the proportion of CP in the fermented OM (NRC 2001). The negative effect of these treatments on ruminal microbial synthesis through the reduction of fermented OM seems to indicate that they are mainly of interest in protein-rich feeds.

Results from the present study of SFM are in agreement with the conclusions of Arroyo et al. $(2011,2013)$ pointing to the higher efficacy of malic acid than orthophosphoric acid to protect proteins. In addition, the inclusion of malate in the diet may provide additional benefits for the ruminal fermentation pattern (Martin and Streeter 1995; Callaway and Martin 1996; Carro et al. 1999).

The range of $\mathrm{MW}$ in polypeptidic bands detected by SDS-PAGE is in agreement with that observed by Spencer et al. (1988) in both feeds. A proposition of band distribution comparing current MW values with literature data is presented in Table 6. An uncertain identification of some polypeptidic bands occurred in SFM, probably because the hexane extraction used in the industrial process may extract cell-wall proteins, which are incorporated to the proteins present in the SDS-PAGE gels, hindering this identification. Albumin disappearance in 0 -h samples of SFM agrees with its soluble character. However, residual albumin that showed in the 0-h sample of the UT-SP meal is in agreement with results of Spencer et al. (1988). These authors found albumin beyond $4 \mathrm{~h}$ of in vitro incubation, indicating that their degradation resistance was almost similar to that of bovine serum albumin, which is usually used as a standard of a protein relatively resistant to rumen degradation. However, the absence of albumin in CS profiles of untreated and treated meals of both feeds show that the practical contribution of albumin to ruminal protein outflow should be near zero even in SP. Bands of CS profiles in both feeds showed lower intensity compared with the original or 0 -h samples, indicating quantitative changes resulting from degradation. The disappearance of polypeptidic bands in CS samples supports higher effects of ruminal degradation in SP than in SFM, which agrees with the quantitative CP degradation results. In vitro studies of Spencer et al. (1988) showed a faster breakdown of major subunits of convicilins, vicilins and $\alpha$-legumin in peas. In addition, Aufrère et al. (1994, 2001) indicated a faster in situ degradation of vicilins and convicilins than legumin in peas. Present results provided partial support to these observations because most disappearing bands in SP have MW corresponding to both vicilins and convicilins. The higher degradation resistance of SP-legumin may be associated with the existence of disulfide bridges not present in the other SP-globulins (Casey and Domoney 1999). No polypeptidic bands were detected after intestinal digestion for SFM. Therefore, the undigested CP contents shown by in situ microbial-corrected data $(4.70 \%, 8.10 \%$ and $6.6 \%$ in UT, MT and PT meals, respectively), should correspond mainly to non-protein compounds or too small peptides, which cannot be detected with SDS-PAGE techniques. These kinds of compounds should also 
be present in intestinally digested SP samples that also showed poorly resolved bands in the low MW areas, probably corresponding to non-digested peptides. The latter observation is in agreement with the low intestinal digestibility shown in situ.

\section{Conclusions}

The protective treatments tested in this experiment decreased the ruminal degradation, displacing the digestion site to the intestine. These effects were higher with malic than with orthophosphoric acid. However, a reduction of the moisture and heat compared with previous technical recommendations decreased the treatment efficacy. Also, the treatments' effectiveness decreased with protein concentration due to the reduction of the ruminal-fermented $\mathrm{OM}$ and, presumably, of the resulting microbial protein synthesis. However, their effectiveness is drastically reduced when anti-nutritive factors are present in the intestine, as seems to be the case in the SP sample tested. Correction for microbial contamination of ruminal-incubated residues was important for the accuracy of current estimates.

\section{Acknowledgements}

This work has been supported by the CICYT-funded Project AGL 2006-08300 and Comunidad de Madrid-funded Projects S2009/ AGR-1704 and MEDGAN ABI-2913. Analyses of ${ }^{15} \mathrm{~N}$ isotope ratios were performed at the 'Servicio Interdepartamental de Investigación, Universidad Autónoma de Madrid’, Spain.

\section{References}

Allen RD, Nessler CL, Thomas TL (1985) Developmental expression of sunflower 11S protein genes. Plant Molecular Biology 5, 165-173. doi: $10.1007 / \mathrm{BF} 00015680$

AOAC (2000) 'Official methods of analysis.' 17th edn. (Association of Official Analytical Chemists: Gaithersburg, MD)

ARC (1984) 'The nutrient requirement of ruminant livestock (Supplement no. 1).' (CAB International: Wallingford, UK)

Arroyo JM, González J (2013) Effects of the ruminal comminution rate and microbial contamination of particles on accuracy of in situ estimates of ruminal degradability and intestinal digestibility of feedstuffs. Journal of Animal Physiology and Animal Nutrition 97, 109-118. doi:10.1111/ j.1439-0396.2011.01248.x

Arroyo JM, González J, Muñoz J, Alvir MR, Rodríguez CA, Ibáñez MA, del Castillo MD (2011) In vitro efficiency of combined acid-heat treatments for protecting sunflower meal proteins against ruminal degradation. Animal 5, 1188-1194. doi:10.1017/S1751731111000279

Arroyo JM, González J, Ouarti M, Silván JM, Ruiz del Castillo ML, de la Peña Moreno F (2013) Malic acid or orthophosphoric acid-heat treatments for protecting sunflower (Helianthus annuus) meal proteins against ruminal degradation and increasing intestinal amino acid supply. Animal 7, 223-231. doi:10.1017/S1751731112001292

Aufrère J, Graviou D, Michalet-Doreau B (1994) Degradation in the rumen of proteins of two legumes: soybean meal and field pea. Reproduction, Nutrition, Development 34, 483-490. doi:10.1051/rnd:19940509

Aufrère J, Graviou D, Melcion JP, Demarquilly C (2001) Degradation in the rumen of lupin (Lupinus albus L.) and pea (Pisum sativum L.) seed proteins: effect of heat treatment. Animal Feed Science and Technology 92, 215-236. doi:10.1016/S0377-8401(01)00262-0

BOE (2005) Real Decreto 1201/2005 'About protection of animals used for experimental and other scientific purposes'. Boletin Oficial del Estado 252, 34367-34391. [In Spanish]
Callaway TR, Martin SA (1996) Effects of organic acid and monensin treatment on in vitro mixed ruminal microorganism fermentation of cracked corn. Journal of Animal Science 74, 1982-1989.

Carro MD, López S, Valdés C, Ovejero FJ (1999) Effect of DL-malate on mixed ruminal microorganism fermentation using the rumen simulation technique (RUSITEC). Animal Feed Science and Technology 79, 279-288. doi:10.1016/S0377-8401(99)00034-6

Casey R (1999) Distribution and some properties of seed globulins. In 'Seeds proteins'. (Eds PR Shewry, R Casey) pp. 159-169. (Kluwer Academic Publishers: Dordrecht)

Casey R, Domoney C (1999) Pea globulins. In 'Seeds proteins'. (Eds PR Shewry, R Casey) pp. 171-204. (Kluwer Academic Publishers: Dordrecht)

Croy RRD, Gatehouse MT, Boulter D (1980) The purification and characterization of a third storage protein (convicilin) from the seeds of pea (Pisum sativum L.). The Biochemical Journal 191, 509-516.

Derbyshire E, Wright DJ, Boulter D (1976) Legumin and vicilin, storage proteins of legume seeds. Phytochemistry 15, 3-24. doi:10.1016/S00319422(00)89046-9

Dhanoa MS, Siddons RC, France J, Gale DL (1985) A multicompartmental model to describe marker excretion patterns in ruminant faeces. British Journal of Nutrition 53, 663-671. doi:10.1079/BJN19850076

Ellis W, Wylie MJ, Matis JH (1979) Quantitating ruminal turnover. Federation Proceedings 38, 2702-2706.

González J, Rodríguez CA, Andrés SG, Alvir MR (1998) Rumen degradability and microbial contamination of fish meal and meat meal measured by the in situ technique. Animal Feed Science and Technology 73, 71-84. doi:10.1016/S0377-8401(98)00132-1

González J, Ouarti M, Rodríguez CA, Alvir MR (2006) Effects of considering the rate of comminution of particles and microbial contamination on the accuracy of in situ studies of feed protein degradability in ruminants. Animal Feed Science and Technology 125, 89-98. doi:10.1016/ j.anifeedsci.2005.05.013

INRA (2007) 'Alimentation des Bovins, Ovins et Caprins. Besoins des Animaux - Valeurs des Aliments, Tables INRA 2007.' (Quae Editions: Versailles, France)

Kortt AA, Cadwell JB (1990) Low molecular weight albumins from sunflower seed: identification of a methionine-rich albumin. Phytochemistry 29, 2805-2810. doi:10.1016/0031-9422(90)87080-E

Kortt AA, Cadwell JB, Lilley GG, Higgins TJV (1991) Aminoacid and cDNA sequences of a methionine-rich $2 \mathrm{~S}$ protein from sunflower seed (Helianthus annuts L.). EuropeanJournal of Biochemistry 195, 329-334. doi:10.1111/j.1432-1033.1991.tb15710.x

Laemmli UK (1970) Cleavage of structural proteins during the assembly of the head of bacteriophage $\mathrm{T}_{4}$. Nature 227, 680-685. doi:10.1038/ $227680 \mathrm{a} 0$

Martin SA, Streeter MN (1995) Effect of malate on in vitro mixed ruminal microorganism fermentation. Journal of Animal Science 73, 2141-2145.

NRC (2001) 'Nutrient requirements of dairy cattle.' 7th revised edn. (National Academy Press: Washington, DC)

O'Kane FE, Happe RP, Vereijken JM, Gruppen H, van Boekel MAJS (2004) Characterization of Pea Vicilin. 1. Denoting Convicilin as the $\alpha$-Subunit of the Pisum Vicilin Family. Journal of Agricultural and Food Chemistry 52, 3141-3148. doi: 10.1021/jf035104i

Ørskov ER, McDonald I (1979) The estimation of protein degradability in the rumen from incubation measurements weighted according to rates of passage. The Journal of Agricultural Science 92, 499-503. doi:10.1017/S0021859600063048

Robertson JB, Van Soest PJ (1981) The detergent system of analysis and its application to human foods. In 'The analysis of dietary fiber in food'. (Eds WPT James, O Theander) pp. 123-142. (Marcel Dekker Inc.: New York)

Rodríguez CA, González J (2006) In situ study of the relevance of bacterial adherence to feed particles on the contamination and accuracy of rumen degradability estimates of feeds of vegetable origin. British Journal of Nutrition 96, 316-325. doi:10.1079/BJN20061830 
Rodríguez CA, González J, Alvir MR, Repetto JL, Centeno C, Lamrani F (2000) Composition of bacteria harvested from the liquid and solid fractions of the rumen of sheep as influenced by feed intake. British Journal of Nutrition 84, 369-376.

SAS (1999) 'SAS/STAT user's guide. Version 8.' (SAS Institute: Cary, NC)

Shewry PR, Pandya MJ (1999) The 2S Albumin Storage Proteins. In 'Seeds proteins'. (Eds PR Shewry, R Casey) pp. 563-586. (Kluwer Academic Publishers: Dordrecht)

Spencer D, Higgins TJV, Freer M, Dove H, Coombe JB (1988) Monitoring the fate of dietary proteins in rumen fluid using gel electrophoresis. British Journal of Nutrition 60, 241-247. doi:10.1079/BJN19880096
Van Soest PJ, Robertson JB, Lewis BA (1991) Methods for dietary fiber, neutral detergent fiber, and non-starch polysaccharides in relation to animal nutrition. Journal of Dairy Science 74, 3583-3597. doi: $10.3168 /$ jds.S0022-0302(91)78551-2

Vázquez JF, Sánchez-Yélamo MD, Carrillo JM (2000) Marcadores morfológicos y bioquímicos. In 'Los marcadores genéticos en la mejora vegetal' . (Eds F Nuez, JM Carrillo) pp. 23-90. (UPV: Valencia) 